\title{
9-3 コンピューター断層撮影の最近の進歩
}

和迩秀信门

\section{1. ま え がき}

“新しい医用X線診断装置”として，X線コンピュー ター断層装置（以下 XCT と略す）が 1973 年 ${ }^{1} に$ 使用さ れて以来 8 年が経過したが，その間にスキャンニング方 式，画像再構成技術，画像表示技術などに急激な進歩22 があった。

本文では XCT の撮影原理について簡単にふれ，方式 の進歩, 画像再構成の技術, 表示の進歩について述べ る.また, 放射性医薬品を体内に注入し, その集積から 体外へ放出される放射線を検出し, ある断面内の放射性 同位元素の分布を求めるエミッションコンピューター断 層 $(\mathrm{ECT})^{3)}$ についても最近の進歩を記述する.

最近では, 核磁気共鳴 $\mathrm{CT}$, 超音波 $\mathrm{CT}$, マイクロ波 $\mathrm{CT}$ などの研究開発む盛んであり, 次代の断層イメージ ング猃断装置として医療の分野で使われるようとしてい るが，乙れらについては簡単に述べ，文献の紹介にとど める.

\section{XCT の進歩}

\section{1 再構成原理}

XCT 画像は“投影からの再構成画像”であり, 再構 成の方法については各種の方法が報告されているが，こ こでは最近のほとんどの CT が採用している重畳積分 法4)について述べる. 重畳積分法は大別すると, その投 影データの得られ方により, 平行ビーム法と扇形ビーム 法の 2 種類になり，乙れらを図 1 亿示す. 平行ビームの 場合は, 検出器と線源が平行移動之回転運動を繰り返 し, 扇形ビームの場合は, 検出器と線源が回転運動だけ を行って投影データを得る.

（1）平行ビームの重畳積分法

図 2 亿示された座標系で, 点 $\left(X_{m}, Y_{m}\right)$ の物体の濃度 を $f\left(X_{m}, Y_{m}\right)$ 之すると, $f\left(X_{m}, Y_{m}\right)$ は物体の $\theta_{j}$ 方向 の投影 $P_{j, l}$ より, 次のような演算で再構成できるとと が証明されている.

まず，投影 $P_{j, l}$ と補正関数 $h_{l}$ を重畳積分する.

†株式会社島津製作所技術研究本部

"9-3 Recent Progress in Computed Tomography" by Hidenobu Wani (Shimadzu Corp., Kyoto)

$$
\text { 平行ビーム法 }
$$

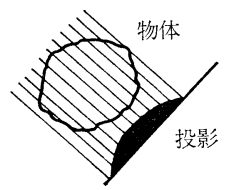

扇形ビーム法

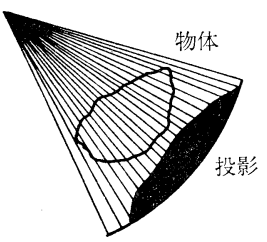

図 1 再構成アルゴリズム

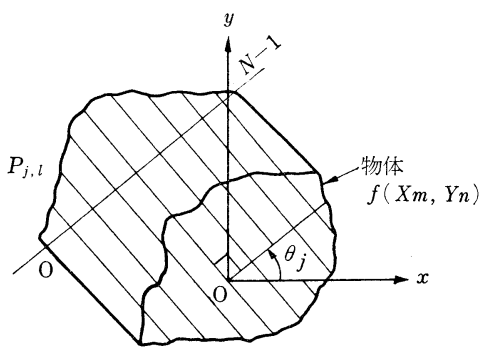

図 2 平行ビームの重畳積分法

$$
P *_{j, k}=\sum_{l=0}^{N-1} h_{k-l} P_{j, l}
$$

ここで $P *_{j, k}$ は補正された投影を示す，通常，補正関 数 $h_{l}$ は画質に大きく影響を及ぼすので各種のもの 提案されている． $P^{*_{j, k}}$ を逆投影することにより，原画 像 $f\left(X_{m}, Y_{m}\right)$ が得られる.

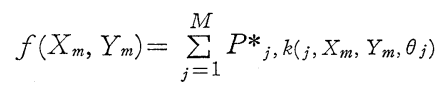

ここで $M$ は投影数を示す. 投影データは $\theta_{j}$ 方向のデ 一タであり, $f\left(X_{m}, Y_{m}\right)$ は直交座標で示されているた め, 計算するときに補間が必要となり, $P_{j}^{*}, k\left(j, X_{m}, Y_{m}, \theta_{j}\right)$ は, $\left.k_{(j}, X_{m}, Y_{m}, \theta_{j}\right)=X_{m} \cos \theta_{j}+Y_{m} \sin \theta_{j}+(N-1) / 2$ を満 足する最む近い整数が $k$ として選択され $k+1$ のデータ を用い内挿して $P^{*}{ }_{j}, k\left(j, X_{m}, Y_{m}, \theta_{j}\right)$ を計算して逆投影さ れる。

(93) 971 


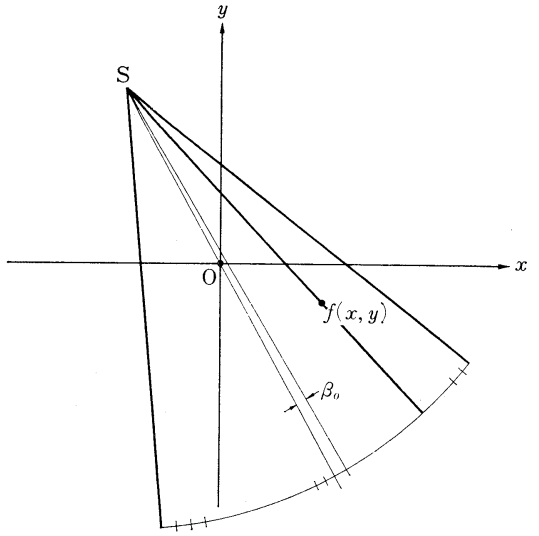

凶３扇形ビームの重畳積分法

（2）扇形ビームの重畳積分法

臨床上，スキャン時間の短縮が要求され，XCT は図 1 に示したような扇気ビームを用いて 2 〜 秒という高 速スキャンが可能になった．乙の扇形ビームが得られる CT では，前節の画像再構成法がそのまま使用できず, $2 つ の$ 方法が開発されている，そのひとつは，扇形ビー

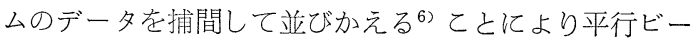
ムを得て, 前節の方法を適用する. 他のひとつは, 扇形ビ

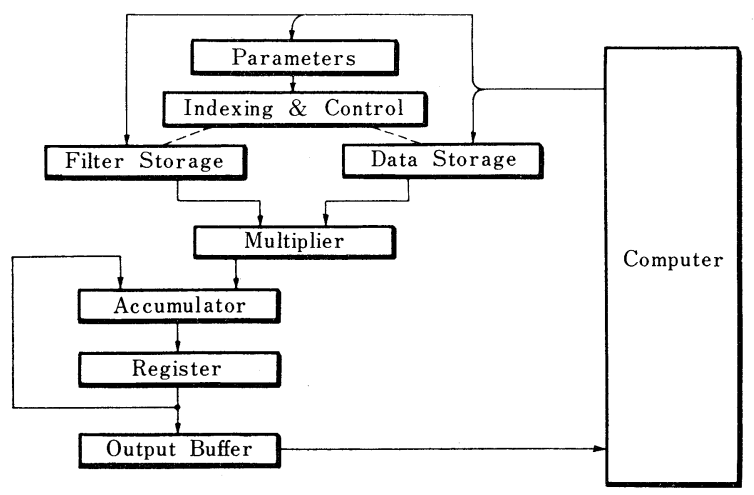

図 4 平行ビーム用コンボルバ

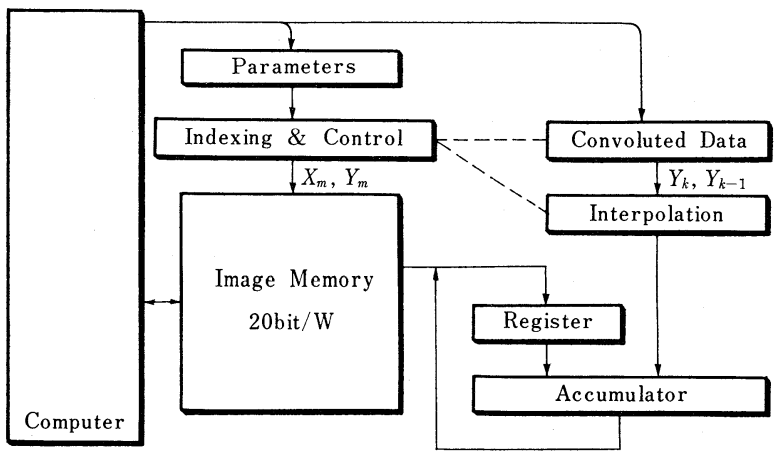

図 5 平行ビーム用バックプロジェクター
ームのデータより直接重畳積分を行う方法で, Herman ${ }^{7)}$ らにより開発された. 図了の座標系で原画像 $f(x, y)$ は

$$
f(x, y) \cong \frac{4}{2 \pi N D \beta_{0}} \sum_{j=1}^{N}\left(\frac{D}{k_{j, x, y}}\right)^{2} \sum_{i=1}^{M} h_{j, x, y}(i) P_{j} *(i)
$$

と表現でき, $N$ は投影の数, $D$ は点 $\mathrm{S}$ と原点 $\mathrm{C}$ との距 離, $\beta_{0}$ は投影データのサンプリング間隔, $k_{j, x, y}$ は点 $(x, y)$ と点 $\mathrm{S}$ との距離, $M$ は投影データのサンプリング 数, $h(i)$ は $P^{*}$ を選別するとき補間するための関数, $P *$ は投影 $P$ と補正関数 $g$ との重疊積分で表現でき,

$$
P_{j} *(i)=\sum_{l=1}^{M} \cos \beta_{l} \cdot P_{j}(l) g(i-l)
$$

となる．乙こで $\beta_{l}$ は， $\beta_{l}=(l-1) \beta_{0}$ で定義される.

\section{2 画像再構成ハードゥェア}

$\mathrm{XCT}$ 装置にはミニコンピューターが不可欠のあのに なっているが, 2.1 節で述べた演算をミニコンピュータ 一で実行させると長時間かかるとととなり，コンボル バ，バックプロジェクターと呼ばれている専用演算器が 開発されている. 図 4 亿平行ビーム用のコンボルバを示 した. Filter Storage に補正関数が蓄わえられ, 計算機 より投影データが Data Storage に送られる.データ転 送の完了と同時に重畳積分の演算はコンボルバの制御の

下で実行される. Multipler と Accumlator によ り積和計算が行われる. Multiplier としては, 16 ビット $\times 16$ ビットの LSI の掛算器などが使用 され, Accumlator としては 4 ビットスライスの バイポーラマイクロコンピューターなどが使用さ れている，重畳積分が完了すると,Output Buffer よりデータが計算機へ転送される.

図 5 には，バックプロジェクターを示した。逆 投影(バックプロジェクション)の演算は，画像メ モリーからデータを読出し，そのデータに投影デ 一タを加算し, 再び画像メモリーに書込む. これ らの専用ハードウェアを用いると通常のスキャン 条件で約 $20 \mathrm{sec}$ で演算が可能になる. 図 6 亿示 したバックプロジェクターは, 図 5 のむのを高速 化したむのである，最近の LSI の進歩はめざま しく, 加算器は低価格で高速のものが入手可能で

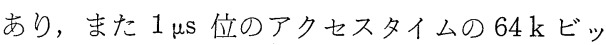
トの RAM む入手可能になったため, 図6のバ ックプロジェクターでは, 一度に 8 方向投影デー タを 1 点に加算している. 原理的に図 5 のバック プロジェクターの8 倍の高速性がある．最近では コンボルバのかわりにアレイプロセッサを用いて いるものもある.これは，よく知られているよう に重畳積分演算は高速フーリエ変換 (FFT) の組 


\section{9. 医用画像処理装置}

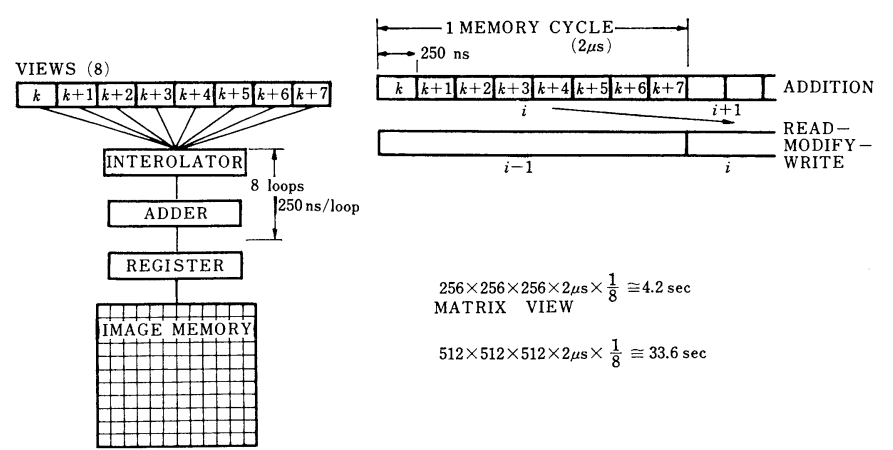

図 6 高速化したバックプロジェクター

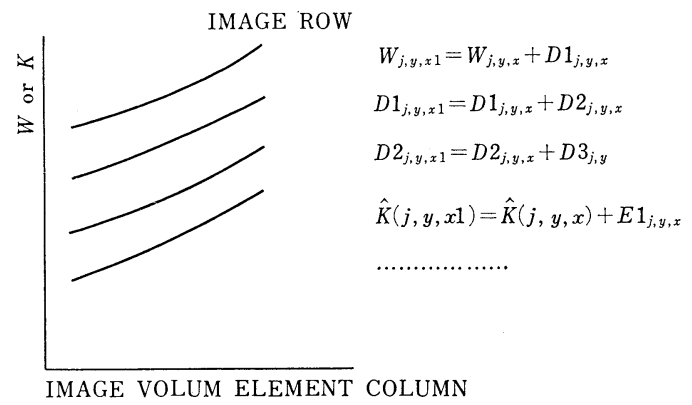

図 7 Weight $(W)$ および Interpolation Factor $(K)$

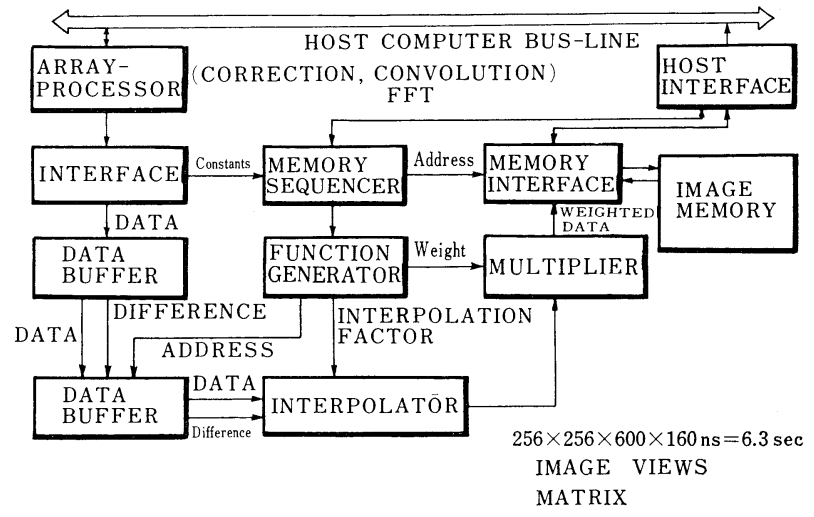

図８扇形ビームバックプロジェクター
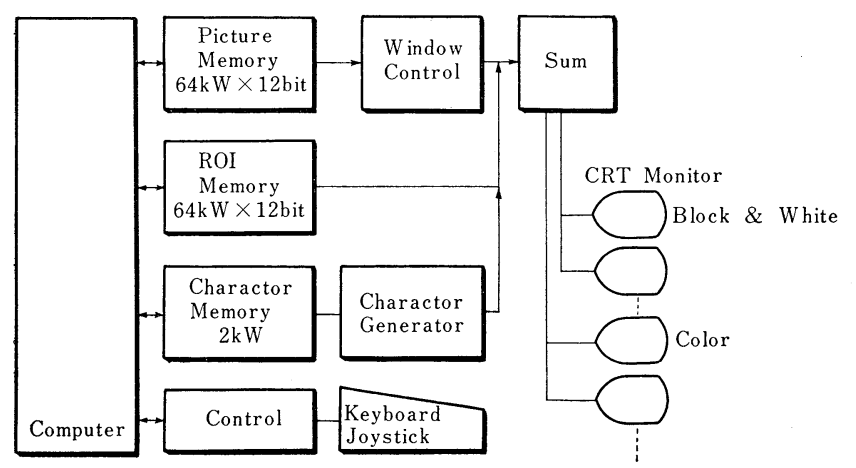

図 9 表示装 置
合せ9)で可能なととを利用している.

扇形ビームの場合は，2.1 節で述べた ように平行ビームに比し計算が複雑にな る. 並びかえ法では，並びかえ専用の八 一ドウェアを開発し，それ以後の演算は 平行ビームと同等であるため, 前述のコ ンボルバ怙よびバックプロジェクターを 用いるととができる.

扇形ビームで直接法を用いる場合は，

(3)式で示したコンボリューション演算 は, 平行ビームに比し, 余弦の掛算が追 加されるが，アレイプロセッサを用いる と我々の経験では， 512 点の投影データ に対して約 $8 \mathrm{~ms}$ で演算が可能であった (コンボリューション演算はFFT の組合 せで行った). バックプロジェクション の過程は，(2)式に示したように平行ビ 一ムに比し Weight $\left(D / k_{j, x, y}\right)^{2}$ 之 Interpolation Factor $h_{j, x, y}(i)$ の演算が加 わる. Weight および Interpolation Factor は画像メモリーの Column と Row の関数として表現すると図 7 のよ うになり，乙れらむ適当な関数で近似 し ${ }^{10)}$, 高速演算を行う. 図 8 亿扇形ビーム バックプロジェクターを示した. バック プロジェクションの基本的操作は, $\mathrm{Me}$ mory Interface により, Image Memory の 1 画素に補正したデータ (Weighted Data）を加算することであり，そのため には Memory Sequencer によりその画 素がぞの投影デー夕に対応するかを知る 必要がある. 重冨積分は, アレイプロセ ッサで行われ，Data Buffer へ送られて いる. Interpolation は Interpolator で 実行され,Function Generator で発生さ れた Weight と Interpolation されたデ 一タが掛算され (Multiplier), Weighted Data が作られる，とれらの各要素はパ イプライン棈造をしており,また Image Memoryは 8 Way の Intereave (多重 処理)を行っているので, 1 点のバックプ ロジェクションは $160 \mathrm{~ns}$ で行っている. このアレイプロセッサとバックプロジェ クターを用いると, 300 方向の投影デー タから $320 \times 256$ の CT 画像が約 $4 \mathrm{sec}$ で構築できる.さらに高速のバックプロ 
ジェクターは Gilbert ら10)により報告されている.

\section{3 画像表示}

$\mathrm{XCT}$ が開発された当初，画像マトリックスは $80 \times 80$ という小さなものであったが，実用化の段階では $160 \times$ 160 位のむのが用いられた，最近では， $512 \times 512$ 位のむ のも用いられている. 図 9 に表示装置の系統図を示し た. XCT 用のディスプレイは，グレイスケールについ ても高分解能が要求されるため, 通常 256 レベル位のむ のが使用されている. 図中の Window Control は, 白 黒の濃淡む拡大して表示するための機能である，ROI Memory は，任意の線画像を CT 画像に重畳して表示 するためのむのである.

\section{3. エミッション CT}

人体に放射性同位元素 (RI) を投与して検査するエミ

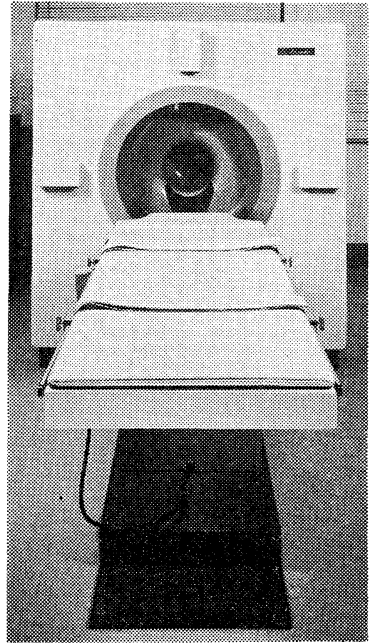
ッション CT が実用化されており，てれら は，99MTcに代表される RI より放出される ケ線を用いるシングルフォトン ECT と, ${ }^{11} \mathrm{C},{ }^{13} \mathrm{~N},{ }^{15} \mathrm{O}$ などのポジトロン放出 RI の消 滅放射線を利用するポジトロン ECT の 2 種 に大別できる.

Kuhl と Edwards ${ }^{11)}$ が 1962 年に RI 断層 像を作成する方法を試みて以来, 多くの $\mathrm{ECT}$ が開発されている．代表的なむのとしては，

Ter-Pogossian らによる PETT シリーズ12? (ポジトロン ECT), Kuhl らによる Mark IV システム13) (シングルフォトン ECT), シン チレーションカメラを使用する $\mathrm{ECT}^{14)}$ があ

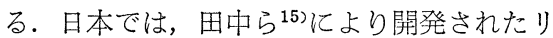
ング状 $\mathrm{ECT}$ ，上村ら ${ }^{16)}$ にるハイブリッド ECTがある．ととでは上村, 管野らとともに 島津が共同開発したポジトロンおびシングル フォトン両用のハイブリッド ECT を紹介し ておく.とのハイブリッド ECTは, HEADTOME と名づけられ，外観を写真1に示し た.

$\gamma$ 線検出器としては, 低エネルギー $\gamma$ 線に 対するエネルギー分解能が良いといわれてい る $\mathrm{NaI}$ 結晶を用いて，乙れらが 64 個リング 状に配列されている. 図 10 にシングルフォ トン用コリメーターの構造を示した. タング ステン板で作った 64 枚の主コリメーター之, それに挾まれた副コリメーターが一齐に左右 に振動して視野を走査するように作られてい る. 主コリメーターの軸には小歯車が取り付 けられており，てれは大歯車と嚙み合ってい

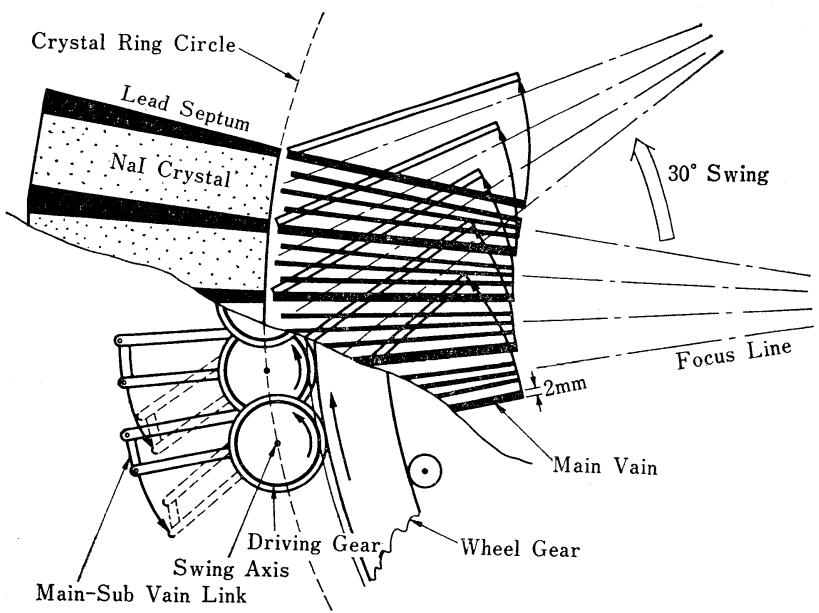

図 10 シングルフォトン用振り角コリメーター
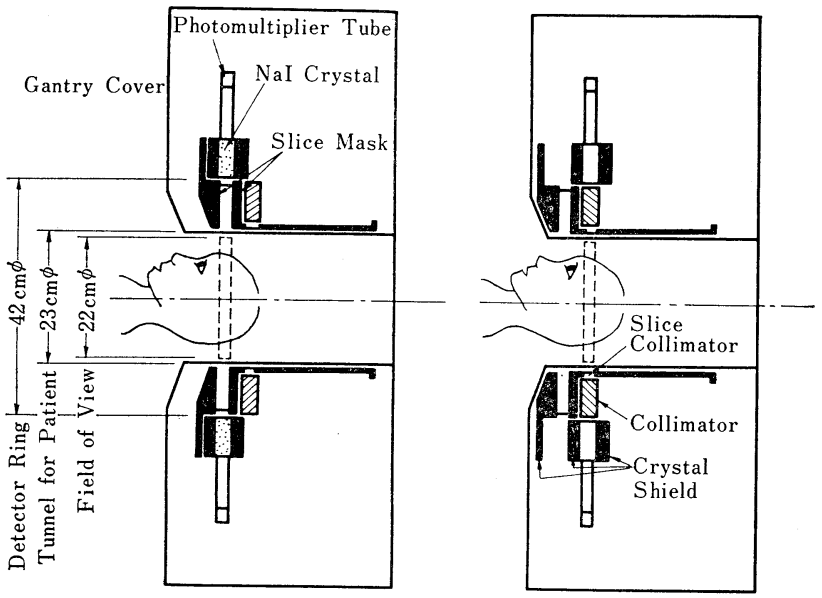

(a) POSITRON DETECTION (b) SINGLE PHOTON DETECTION 図 11 コリメーターシールドの切換え 
る. 大歯車がパルスモーターによって矢印方向に往復運 動し,コリメーターが振子運動を行う.

ポジトロン ECT として使用する時は, このコリメー ターは奥へ引込み, 散乱線除去用のドーナツ形鉛シール ドがコリメーターのあった位置へ引き出されて来る. 図 11 にコリメーターの切り換え方法す示した. また検出器 およびコリメーターは細かくデータを取るために，回転 およびゆすり運動ができるようになっている，とのハイ ブリッド ECT は, 秋田県立脳血管研究センターで臨床 試用中であり，またその改良形の HEADTOME-II が 開発された.

\section{4. その他の $\mathrm{CT}$}

現在 CT は多様化しており，その中には，人体内物質 の核磁気共鳴現象を計測する NMR-CT ${ }^{17)}$, 超音波の体 内での減衰や伝搬速度を計測する US-CT ${ }^{9}$, マイクロ ウェーブを利用したCTなどがあり, 研究開発がすすめ られている。この中です NMR-CT は最む開発が進ん でおり，乙の 1 年以内には日本でむ臨床試用が行われよ うとしている.

\section{5.む す び}

XCT の画像処理の進歩, ハイブリッド ECT を中心 として述べてきたが，紙面の都合上充分解説できなかっ たところあある. 関心のある方は, 参照文献に詳しく述 べられているので，それらを参照されたい.

(昭和 56 年 5 月 28 日受付)

\section{〔参考 文 献〕}

1) G. N. Hounsfield: Computerized transverse axial scanning (tomography), Brit. J. Radio., 46 (1973) 1016-1022

2）飯沼, 遠藤：コンピュータ断層の最近の進歩, 計測と制 御，18，10 (1979) 835-847

3) T.F. Budinger, et al: Emission Computed Tomograpy in Image Reconstruction from Projections,
G. T. Herman, Ed., Springer-Verlag, New York (1979) $147-246$

4) G. N. Ramachandran, A. V. Lakshminarayanan: Three dimensional reconstruction from projection from radiographs and electron micrographs: application of convolutions instead of Fourier transforms, Proc. Nat. Acad. Sci. U.S., 68 (1971) 22362240

5) L. A. Shepp, B. F. Logan: The Fourier reconstruction of a head, IEEE Trans., NS-21 (1974) 21-43

6) T.M. Peters, R. M. Lewitt: Computer tomography with fan beam geometry, J. Comput. Assisted Tomography, 1 (1977) 429-436

7) G. T. Herman, et al: Canvolution reconstruction techniques for divergent beams. Comput. Biol. Med., 6 (1976) 259-271

8) 和迩ほか: "Real-time image processing in CT convolver and back projector" inReal-time medical image processing, Plenum Press (1980) 99-106

9) A.C. Kak: Computerized tomography with X-ray emission and ultra sound soureces, Proc. IEEE, 67 (1979) 1245-1272

10) B.K. Gilbert: Rapid exeaction of fan beam Image reconstruction algorithms using efficient computational techniques and special-purpose processors, IEEE Trans., BME-28 (1981) 98-116

11) D. E. Kuhl, R. Q. Edwards: Image separation radioisotope scanning, Radiology, 80 (1963) 653-661

12) Ter-Pogossian, et al: A multi-slice positron emission computed tomography (PETT IV), Radiology, 128 (1978) 477-484

13) D. E. Kuhl, et al: The Mark IV system for radionuclide computed tomography of the brain, Radiology, 121 (1976) 405-413

14) R. J. Jaszczak, et al: Radionuclide emission computed tomography of the head with ${ }^{99 \mathrm{M}} \mathrm{TC}$ and a scintilation camera, J. Nucl. Med., 18 (1977) 373-380

15) 田中ほか: "Positology"-The search for ouitable defector Arrangements for a positron ECT with continuous rotation, IEEE Trans., NS-26 (1979) 2728-2732

16)上村ほか：HEADTOME-I の開発とその臨床, 島津評 論, 37 (1980) 221

17) P. Mansfield, et a1: Medical imaging by NMR, Brit. J. Radiol., 50 (1977) 188-194 